\title{
Structural Capital Development and Intra-Organizational Integration of Premium Restaurants In Rivers State, Nigeria
}

\author{
Obiora, Judipat Nkiru (PhD) \\ Department of Hospitality Management and Tourism, \\ Faculty of Management Sciences, University of Port Harcourt, Rivers State, Nigeria
}

\begin{abstract}
The imperatives of intra organizational integration anchor on the establishment of systemic features necessary for organizational effectiveness and efficiency. Such outcomes border on the support and frame work advanced by the structural components of the organization, and the extent to which infrastructures and norms serve the goal of improved service quality and delivery especially within the hospitality industry. This paper identified structural capital development as a significant predictor of intra organizational integration (communication and knowledge sharing) in premium restaurants in Rivers State, Nigeria - thus, reinforcing the institutional theory on the criticality of learning and the embodiment of external values and considerations in shaping or defining organizational structures, routines and policies. The findings however indicate that structural capital does not influence cohesion within the premium restaurants. In conclusion, emphasis is placed on the imperatives of informed change activities channelled o wards organizational infrastructure and functions; such that anchor on the unique characteristics or attributes of the environment; thus enabling a more harmonic and systemic outcome for the internal as well as external features of the organization
\end{abstract}

Keywords: Premium restaurants, Fine dining, hospitality industry, intraorganizational integration, structural capital development.

\section{Introduction}

Premium (otherwise referred to as fine dining) restaurants are considered as the most formal and high quality of restaurants within the hospitality industry (Daniel, 2015). The growing preference for these forms of restaurants in Nigeria stems from their noted quality and high-taste service features which are structured to accommodate both foreign and local nationals with considerable tastes for aesthetic and serene environments (Agu, Kalu \& Agaeze, 2017). Hence there is a noted increase in the competition within the context of this category of organizations. To survive and thrive, organizations, irrespective of their nomenclature, must be able to consistently stand-out in their service features, while at the same time maintain optimality in their operations and functions (Obiora \& Okpu, 2018). However, this is only possible where these restaurants are able to achieve intra-organizational integration (Agwu, 2014). Daniel (2015) identified poor functional synchronization and weak operational links as impacting negatively on the wellbeing and integration of these restaurants. According to Agu et al (2017) and Nwokorie \& Obiora (2018), most organizations are unable to sustain their initial enthusiasm from the early years due to structural changes and lapses in operations accruing over years from new recruits, changes in technologies and even the increase or the growth of the business.

Intra-organizational integration refers to the internal synchronization of organizational functions and operations (Peyrefitte, Golden \& Brice, 2002). Afuah (2011) posited that integration enables the fusing of values, skills and organizational systems in a way that provides support and increased knowledge sharing, necessary for the performance of organizations. Parry, Fenin and Gonzalez (2010) identified both dimensions of integration (functional and operational) as providing the necessary condition of synchrony that allows for skills to be adequately utilized and applied in the processes and actions of the organization. Related studies (Pimenta, Da Silva \& Tate, 2016; Peyrefitte et al, 2002; Troy, Hirunyawipada \& Paswan, 
2008) appear congruent on the imperatives of Intra-organizational integration for the success and long-term well-being of the organization. According to Agwu (2014) the nagging issues reflected in the ineffectiveness and inefficiency of most organizations in Nigeria, does not necessarily emerge from their lack of resources or deficiencies in the skills of their human resources, but rather in the lapses of their systems, policies or infrastructure to advance the required frameworks necessary for effectively bridging the various differences and conflicts of interest that are manifested within the organization by its various units, groups and levels.

The development of structural capital is considered as imperative to the framing of work systems that are supportive of workers functions and aid in the performance of their roles (Ofurum \& Aliyu, 2018). Structural capital according to Anuonye (2016) involves the various infrastructures, methods and routines that condition the workers experience and operations within the organization. Baye and Douanla (2014) posited that new knowledge and learning improves the structural capital of the organization, enriching its features and the ways through which it patterns the behaviour and actions of the organizations human resource. In their research Tarigan, Listijabudhi, Hatane and Widjaja (2019) identified a link between structural capital and the performance of the organization. Their observations are reiterated by Bailoa (2017) who identified structural capital as contributing towards the organizations operational efficiency; stressing on the need for improved structural systems and database functions as a basis for enhancing workplace cohesion and interfunctional coordination. Little, however, has addressed the relationship between structural capital development and intra-organizational integration especially within the context of the hospitality industry of African countries such as Nigeria. This paper thus focused on the role of structural capital development in improving intra-organizational integration (especially with regards to measures such as communication, cohesion and knowledge sharing) in premium restaurants in Rivers State, Nigeria. The institutional theory is adopted as the theoretical framework within which this paper is anchored.

\section{Literature Review \\ Institutional theory}

The institutional theory is a theory of how institutions emerge and thrive. It is one which identifies the processes and ways in which social norms, values, policies and structures are adopted and adapted over time (Scott, 2004). Institutions refer to social structures which have been able to sustain operations and functions in a consistent manner over a period of time (Miller, 2007). The concerns of the institutional theory are such that therefore seek to understand and explain the nature of rules, regulations, frameworks and structures that define institutions; and how these enable the institutions to survive or thrive within their specific contexts. Cooper, Ezzamel and Willmott (2008) observed that in line with Scott (2004) position, effective policies and structures emerge from the environment of the organization and that way, enables the organization align itself effectively with its market and context. This agrees with Miller (2007) who posited that as open systems, organization should be willing and able to adapt structural forms and systems that are patterned towards bridging their service or functional gaps within the same environment. Miller (2007) argued that in the development of structural forms it is important that organizations build on learning and knowledge from their interaction with both internal and external stakeholders of the organization. This is necessary for the pooling of ideas, the specification of satisfaction gaps and also for enhancing the extent of creative solutions towards addressing the problems of the organization.

\section{Structural Capital Development}

The structural capital of the organization describes its supportive infrastructures, database systems, routines, processes and the various frameworks that aid and furnish the activities and functions of the organizations human resource (Edeh \& Anyanwu, 2015). Jardon and Martos (2012) opined that an organization's forms emerge from their structures, which serve the particular purpose of aligning functions and responsibilities efficiently and effectively. Rudez and Tanja (2007) noted that despite the changes, influx or outflux of human personnel, the structural capital of the organization is considered its own and remains with the organization. However, given the changes in its market and the need for improved functionality, organizations may decide to further develop or adapt the features of their structural capital so as to enrich and strengthen operations (Veeramani and Chandrasekaran, 2017; Ramezzan, 2011). Thus, structural capital development stems from the organizations intent to strengthen and improve on its existing structural forms as a basis for enhancing its functionality and the value it offers its clients or customers. Andreeva and Garanina (2017) asserted that the health and wellbeing of the organization as well as its capacity for quality 
service, borders on the nature and suitability of its structures in line with the attributes of its market or environment.

\section{Intra-organizational integration}

Integration refers to the unification and effective synchronization of the various parts, activities, process and units of a system. Within the organization, integration is imperative for sustaining healthy communication, collaboration and information or knowledge sharing across the functions and levels of the organization (Wong, Boonitt \& Wong, 2011). In this way, intra-organizational integration is a reflection of how unified and systemic the organizations units, functions and processes are. Maiga, Nilsson and Ax (2015) reported that a good number of organizations within the hospitality industry, covering hotels, lodges and restaurants are plagued with the challenge of poor integration. While they may appear effective, their capacities and the quality of their services could yet be improved upon through the thoroughness advanced by the increased cooperation between the various units and levels in the organization. Sagawa and Nagano (2015) argued that intra-organizational integration implies a situation where the organization is able to harmonize its systems and operation such that allows for improved outcomes of interfunctional coordination, efficiency and effectiveness. Studies (Zahay \& Griffin, 2014; Kaipia et al, 2017; Donaldson, 2001) have so far emphasized on three facets of integration, namely - (a) communication (b) cohesion, and (c) knowledge sharing.

Communication within the context of intra-organizational integration describes the flow of information and correspondence between the various functions (horizontal) and levels (vertical) in the organization (Kaipia et al, 2017). Communication is also an indication of transparency and the extent to which it's various parts, levels and units are carried along. Cohesion, as a measure of integration describes the extent to which the various human elements and functions of the organization are fused and as such agree in terms of focus, values and priorities (Edeh \& Anyawu, 2015). Cohesion is imperative for organizational consistency as individual and group behaviours are noted to align with those of the organization (Edeh \& Anyawu, 2015; Buowari, 2015). Furthermore, cohesion denotes unity and a shared sense of responsibility to the organization. Knowledge sharing which is the third measure of intraorganizational integration, details the extent to which organizational parts or units are interdependent and reliant on each other's skills, knowledge and capacities. Knowledge sharing in this manner provides for a circulation and dispersion of knowledge and skills within the organization (Buowari, 2015).

\section{Structural Capital Development and Intra-organizational Integration}

The designs and structures of organizations provide for the infusing of skills, actions and behaviour that enable the health and optimal operations of the organization (Nimtrakoon, 2015). Poor infrastructures, role ambiguity and inconsistent routines are deterring not only to the performance of the organizations human resource but also to the wellbeing of the organization as well. Okoye et al (2015) argued that the development of the organizations structural capital begins with an understanding of the organizations fitting within its context and the ways through which new or adapted structures match the needs of the organization. This understanding further enables the restructuring of roles and units using parameters that not only build on the overall outcomes of performance but such that ensure that the various components of the organization are adequately fused and synchronized (Oforum \& Aliyu, 2018). Baye and Douanha (2014) in their research noted that the lack in systemic qualities produces disjointed and dysfunctional parts, which tend to focus on driving objectives which in the long-run may be detrimental to the wellbeing of the organization as a whole. This is as Bontis et al (2002) affirmed that the rearranging of structural forms and roles to suit demand flow or to strengthen particular service lines. However, given the noted gap in empirical research addressing the relationship between structural capital development and intraorganizational integration within the context of premium restaurants in Rivers State, the following hypotheses are stated:

$\mathrm{HO}_{1}$ : There is no significant relationship between structural capital development and communication in premium restaurants in Rivers State

$\mathrm{HO}_{2}$ : There is no significant relationship between structural capital development and cohesion in premium restaurants in Rivers State

$\mathrm{HO}_{3}$ : There is no significant relationship between structural capital development and knowledge sharing in premium restaurants in Rivers State 


\section{Methodology}

The methodology adopted for this research is the quantitative method and the design is the correlational design. The deductive approach is also adopted in that hypotheses draw on existing theoretical frameworks which are tested and validated based on the observations or results generated. The population comprised 82 management and junior staff within 10 premium (fine dining) restaurants in Rivers State as sourced from TripAdvisor (2021). A census was adopted given the size of the population and all 82 staff of the 10 premium restaurants was adopted as units of measurement in the investigation. Data for the study was sourced primarily using the structured questionnaire format. The instrument for structural capital development was adapted from Bailoa (2017) while the multi-dimensional measurement of intraorganizational integration (communication, cohesion and knowledge sharing) was adapted from Peyrefitte et al (2002). Scaling for the questionnaire following a slightly modified Likert scale of $1=$ strongly disagree, 2 $=$ disagree, $3=$ moderately agree, $4=$ agree and $5=$ strongly agree. All instruments were adapted into 4 indicator measures and all stated in the positive. The reliability test for the instruments was carried out using the Cronbach alpha reliability test tool with all coefficients observed at alpha (a) $>0.70$ indicating clarity and replicability of the instruments.

\section{Data Results}

The univariate analysis and data distribution for the variables revealed substantial levels of manifestations of all four variables within the context of the premium restaurants in Rivers State. The result for the univariate analysis on the evidence for the variables is illustrated on table 1:

Table 1: Summaries for data distribution for the variables

\begin{tabular}{|l|l|r|r|r|r|}
\hline \multicolumn{2}{|c|}{} & $\begin{array}{c}\text { Structural Capital } \\
\text { Development }\end{array}$ & $\begin{array}{r}\text { Communicatio } \\
\mathrm{n}\end{array}$ & Cohesion & \multicolumn{2}{c|}{$\begin{array}{c}\text { Knowledge } \\
\text { Sharing }\end{array}$} \\
\hline $\mathrm{N}$ & Valid & 80 & 80 & 80 & 80 \\
\cline { 2 - 6 } & $\begin{array}{l}\text { Missin } \\
\mathrm{g}\end{array}$ & 0 & 0 & 0 & 0 \\
\hline Mean & 3.4160 & 3.5333 & 3.5583 & 3.5229 \\
\hline Std. Deviation & .68299 & .73653 & .59481 & .58446 \\
\hline Skewness & -.051 & -.234 & -.233 & -.578 \\
\hline Std. Error of Skewness & .269 & .269 & .269 & .269 \\
\hline Kurtosis & -1.022 & -1.047 & -.042 & -.151 \\
\hline \multicolumn{2}{|l|}{ Std. Error of Kurtosis } & .532 & .532 & .532 & .532 \\
\hline
\end{tabular}

Source: Research data, 2021

The distributions for structural capital development $(\mathrm{x}=3.4160)$ suggest a shared position on related actions concerned with learning through interaction and feedback from customers, vendors and even the employees. These provide focus as to what infrastructural features or design requires reconfiguring and the areas lagging in terms of functional support. For communication $(x=3.5333)$, the results show that there is substantial evidence which supports the effectiveness of communication across the various units of the organization. This captures both briefings and correspondence across levels and units within the workplace. On cohesion $(x=3.5583)$, evidence indicates that units and levels within the organization agree and can be described as unified in their value and actions. The manifestations of knowledge sharing $(\mathrm{x}=3.5229)$ are also evident within the context of the study, affirming to the transfer and sharing of skills and expertise across the units or functions of the organization. 


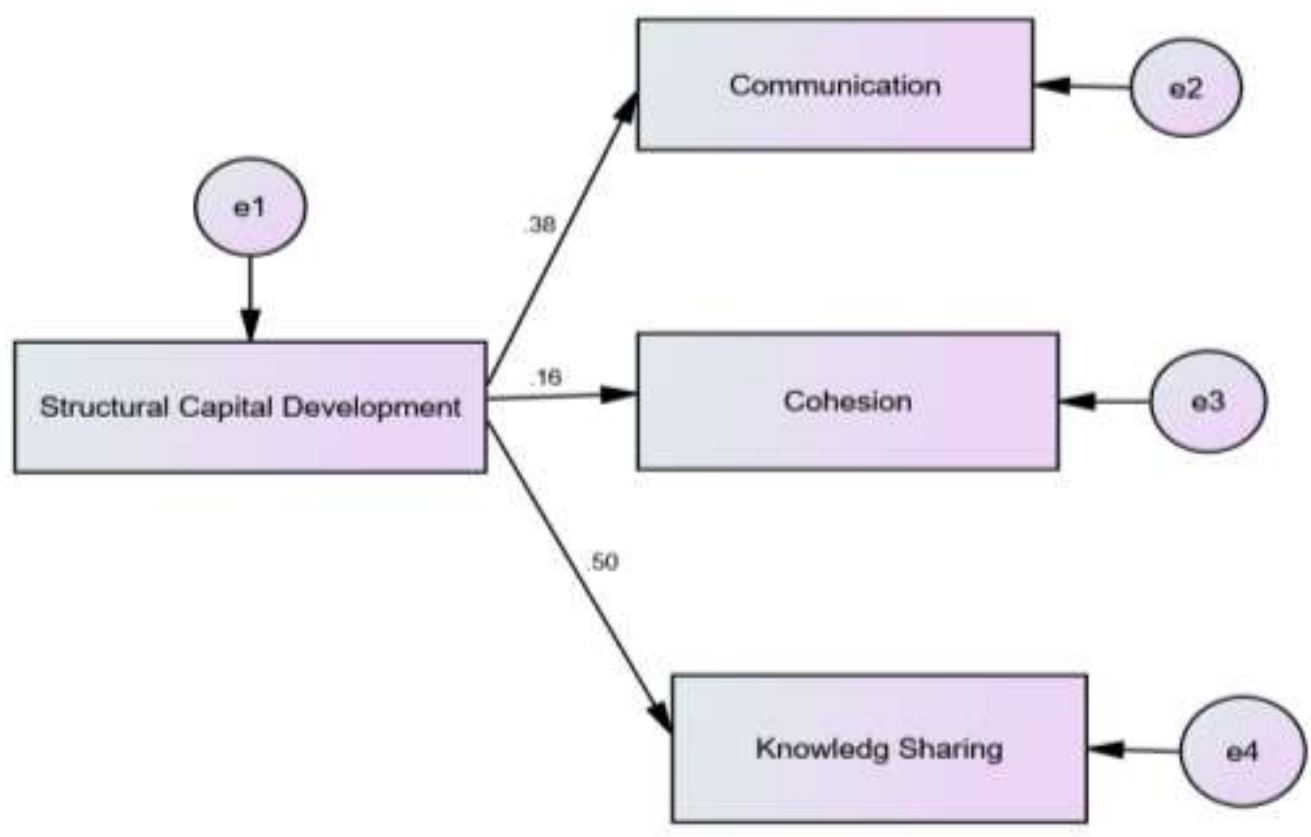

Figure 1: Amos based model on the relationship between the variables

Table 1: Correlations between the variables

\begin{tabular}{|l|rrrr|}
\hline & Structure & Knowledge & Cohesion & Communication \\
\hline Structure & 1.000 & & & \\
Knowledge & .503 & 1.000 & & \\
Cohesion & .160 & .080 & 1.000 & \\
Communication & .384 & .193 & .061 & 1.000 \\
\hline
\end{tabular}

Source: Research data, 2021

Tests for the hypotheses using standardized regression weights and probability values generated by AMOS graphics (figure 1) indicate that structural capital development has a significant and positive effect on communication $(\mathrm{R}=0.384 ; \mathrm{P}=0.000)$ and knowledge sharing $(\mathrm{R}=0.503 ; \mathrm{P}=0.000)$; however, the effect of structural capital development on cohesion is weak and insignificant $(\mathrm{R}=0.163 ; \mathrm{P}=0.150)$. Results indicate that the relationship between structural capital development and knowledge sharing is more evident and dominant as compared to that of communication. Thus, it follows that the development of existing infrastructure, routines and database systems within the premium restaurants significantly contribute towards improved outcomes of knowledge sharing and communication within the restaurants; unfortunately, these forms of structural capital do not significantly impact or drive the level of cohesion within the organization. Thus, evidence supports the position that:

i. Structural capital development significantly impacts on communication in premium restaurants in Rivers State

ii. Structural capital development does not significantly influence cohesion in premium restaurants in Rivers State

iii. Structural capital development significantly contributes towards knowledge sharing in premium restaurants in Rivers State

\section{Discussion and Conclusion}

The effect of structural capital development on organizational integration outcomes such as knowledge sharing and communication, demonstrate the imperatives of established database systems in driving information access and skill transfer across the workplace. Results from the test on these relationships agree 
and reiterate the views of Rudez and Tanja (2007), reinforcing stated imperatives for clarity in reporting lines, routine and functional methods in the organization. However, the evidence from this study does not support the relationship between structural capital development and cohesion. Earlier studies (Edeh \& Anyawun, 2015; Okoye et al, 2015) indicate that the development of infrastructures and data networks drive unit integration and enhances members shared values and compliance to established operational standards. While cohesion is observed to characterize the premium restaurants, the evidence does not link such manifestations as being a consequence of structural capital development.

The findings of this study nonetheless validate the institutional theory in view of its position on the establishment of norms, structures and policies, building on the context of the organization (Cooper et al, 2008). The implications follow that effective engagement of the environment and the stakeholders of the organization, advances its knowledge content and enables a transformation suited to the gaps within the context of the organization. Thus through structural capital development, management is able to align itself internally and reconfigure itself in terms of communication and knowledge sharing so as to boost its service features and overall performance (Pinto \& Pinto, 2008; Daniel, 2015). It is therefore recommended that the development of structural capital by managers, could be a valuable part of an organization's development strategy as a way to create and enhance members team spirit and trigger off improved organisational processes. In conclusion, this research provides a position on the imperatives of informed change activities channelled towards its infrastructure and functions; such that anchor on the unique characteristics or attributes of its environment; thus enabling a more harmonic and systemic outcome for the internal as well as external features of the organization.

\section{References}

1. Afuah A. (2011): Dynamic boundaries of the firm: Are firms better off being vertically integrated in the face of technological change. Academy of Management Journal, 44(6):1211-1228.

2. Agu, G. A., Kalu, I. N., \& Agaeze, C. (2017). Fast food restaurant image and sustainable customer loyalty in a period of economic recession. International Journal of Social Sciences and Humanities Review, 7(2), 1-10

3. Agwu, M. O. (2014). Issues, challenges, and prospects of small and medium scale enterprises (SMEs) in Port Harcourt City, Nigeria. European Journal of Sustainable Development, 3, 101-114

4. Andreeva, T., \& Garanina, T. (2017). Intellectual Capital and Its Impact on the Financial Performance of Russian Manufacturing Companies. Foresight and STI governance, 11(1), 31-40.

5. Anuonye, N. B. (2016). Effect of intellectual capital on return on assets of insurance firms in Nigeria. Global Journal of Management and Business Research: C Finance, 16(1), 40-51.

6. Bailoa, S. I. R. (2017). Intellectual capital: The strategic resource of organizations. The Małopolska School of Economics in Tarnów Research Papers Collection, 36(4), 57-75.

7. Baye, F. M., \& Douanla, J. (2014). Impact of intellectual capital efficiency on the financial performance of financial institutions in Yaounde, Cameroon. International Journal of Arts and Commerce, 3(4), 166-187.

8. Bontis, N., Crossan, M.M. and Hulland, J. (2002), "Managing an organisational learning system by aligning stocks and flows", Journal of Management Studies, 39 (4), 437-69.

9. Buowari, P. E. (2015). Factors required for small business sustainability in Nigeria. Retrieved from http://scholarworks.waldenu.edu/dissertations/1775/

10. Cooper, D. J., Ezzamel, M., \& Willmott, H. (2008). Examining “institutionalization": A critical theoretic perspective. The Sage handbook of organizational institutionalism, 673-701.

11. Daniel, E. C. (2015). Compensation strategies and job mobility in fast-food restaurants in Port Harcourt. International Journal of Management Science, 4(6), 316-325

12. Donaldson, L. (2001). The Contingency Theory of Organizations. Thousands Oaks, CA: Sage

13. Edeh, F.O., \& Anyanwu, S.A.C (2015). Social intelligence and team cohesiveness. A study of selected hospitality firms in Port Harcourt. MSc Thesis University of Port Harcourt.

14. Jardón, C. M., \& Martos, M. S. (2012). Intellectual capital as competitive advantage in emerging clusters in Latin America. Journal of Intellectual Capital, 13(4), 462-481. 
15. Kaipia, R., Holmstr€om, J., Smaros, J., \& Rajala, R. (2017). Information sharing for sales and operations planning: Contextualized solutions and mechanisms. Journal of Operations Management, $52,15-29$.

16. Maiga, A.S., Nilsson, A., \& Ax, C. (2015). Relationships between internal and external information systems integration, cost and quality performance, and firm profitability. International Journal of Production Economics, 169(November), 422-434.

17. Miller, Clark A. 2007. "Democratization, International Knowledge Institutions, and Global Governance." Governance 20:325-357.

18. Nimtrakoon, S. (2015). The relationship between intellectual capital, firms' market value and financial performance. Journal of Intellectual Capital, 16(3), 587-618.

19. Nwokorie, E, C. \& Obiora, J. N. (2018): Sustainable development practices for the hotel industry in Nigeria: Implications for the Ilaro area of Ogun State. Research in Hospitality Management. 8(2), 125-131,

20. Obiora, J.N. \& Okpu, T. (2018): The Impact of Cognitive Capital on Corporate Learning in Selected Hotels in Anambra State, Nigeria. International Journal of Operational Research in Management, Social Sciences and Education, 4(1), 189-198

21. Ofurum, C. O. \& Aliyu, A. S. (2018). Intellectual capital component and financial performance of quoted banks in Nigeria. International Journal of Advanced Academic Research, 4(2), 24-46.

22. Okoye, I. E., Aroh, N. N., \& Egbunike, A. P. (2015). Empirical examination of integrated component of intellectual capital on financial performance: a study of select service and non-service firms in Nigeria. Social and Basic Sciences Research Review, 3(9), 299-315.

23. Parry M E, Ferrín P F, González J A V, (2010). PERSPECTIVE: Cross-Functional Integration in Spanish Firms. Journal of Product Innovation Management, 27(4):606-615.

24. Peyrefitte, J., Golden, P.A., \& Brice J. (2002). Vertical integration and economic performance: A managerial capability framework. Journal of Management Decision, 40(3), 217-226.

25. Pimenta, M.L., da Silva, A.L., \& Tate, W.L. (2016). Characteristics of cross-functional integration processes: Evidence from Brazilian organizations. The International Journal of Logistics Management, 27(2), 570-594.

26. Pinto M B, Pinto J K. (2008): Project Team Communication and Cross-Functional Cooperation in New Program Development. Journal of Product Innovation Management, 7(3):200-212.

27. Ramezan, M. (2011). Intellectual capital and organizational organic structure in knowledge society: How are these concepts related? International Journal of Information Management, 31, 88-95.

28. Rudez, HN, \& M. Tanja (2007) "Intellectual Capital In The Hotel Industry: A Case Study From Slovenia", Hospitality Management 26, pp.188-199.

29. Sagawa, J.K., \& Nagano, M.S. (2015). Integration, uncertainty, information quality, and performance: A review of empirical research. International Journal of Advanced Manufacturing Technology, 79(1), 299-306.

30. Scott, W. R. (2004). Encyclopedia of social theory. Institutional theory. In, 408-14.

31. Tarigan, J., Listijabudhi, S., Hatane, S. E., \& Widjaja, D. C. (2019). The impact of intellectual capital on financial performance: An evidence from Indonesian manufacturing industry. Indonesian Journal of Business and Entrepreneurship, 5(1), 65-76.

32. Troy LC, Hirunyawipada T, Paswan A K. (2008): Cross-Functional Integration and New Product Success: An Empirical Investigation of the Findings. Journal of Marketing , 72(6):132-146.

33. Veeramani, C. \& Chandrasekaran, R. (2017). Impact of human capital challenges on organizational commitment: An empirical study in Tangedco. International Journal of Human Resource Management and Research, 7(6) 25-34.

34. Wong, C.Y., Boon-itt, S., \& Wong, C.W.Y. (2011). The contingency effects of environmental uncertainty on the relationship between supply chain integration and operational performance. Journal of Operations Management, 29(6), 604-615.

35. Zahay D. \& Griffin A. (2014): Customer Learning Processes, Strategy Selection, and Performance in Business-to-Business Service Firms. Decision Sciences, 35(2):169-203. 